\title{
SOCIAL EFFECTS OF TERRORISM ON YOUNG INDIVIDUALS IN NORTH- EAST NIGERIA
}

\author{
Ujene, I. G.
}

Department of Sociology, University of Ibadan, Ibadan, Oyo State, Nigeria

Phone: +2348133419950 Email: profikechukwu@gmail.com

\begin{abstract}
Terror and wars are not recent events as they had always existed with mankind since creation. According to Charles Darwin, in his concept of "survival of the fittest," only the strong survive and this statement had gone ahead overtime to prove its validity both domestically and the world over. Although wars are not new, their effects (especially social effects) such as the effect on religion, destruction of social networks and support, functional impairment, conduct disorder (deviance), destruction of social capitals, destruction of social institutions and on young people cannot be ignored since every action is consequential. Nigeria is not an exception to terrorisms, wars and insurgencies as can be proven by her most recent histories; there had been the civil war, Niger-Delta insurgency and now the terroristic act of Boko Haram in the North-East. Due to the numerous effects of war, there are many scholarly works on psychological, biological and the economic dimensions but the social effects of terror such as is currently going on in North-East Nigeria are more trans-generational and have a more diverse outlook, despite this, there is the silence of literature on such effects thus, the aptness of this work. This paper underscores the social effects of the ongoing insurgence of Boko Haram in the North-East Nigeria on young individuals. Although United Nations in 1981 designated 1524 years as youths, this study adopts 13-24 years for a wider coverage due to the historic-religious and cultural documentations and evidences of early marriages among the people under study. Theoretically, structural functionalism is apt in the explanation of this growing situation and it submits that the Nigerian state should pay much attention on development, Nigeria should explore the informal education sector and that religion of any kind should be de-radicalized and any iota of inciting messages should be expunged from worship places.
\end{abstract}

Keywords: conduct disorder, functional impairment, post-traumatic stress disorder (PTSD), terrorism, young people

LICENSE: This work by Open Journals Nigeria is licensed and published under the Creative Commons Attribution License 4.0 International License, which permits unrestricted use, distribution, and reproduction in any medium, provided this article is duly cited.

COPYRIGHT: The Author(s) completely retain the copyright of this published article.

OPEN ACCESS: The Author(s) approves that this article remains permanently online in the open access (OA) mode.

QA: This Article is published in line with "COPE (Committee on Publication Ethics) and PIE (Publication Integrity \& Ethics)". 


\section{INTRODUCTION}

Nigeria is considered the most populated Black Nation in the world over with a documented population of one hundred and forty million (National Population Commission, 2006) but with a current estimation of one hundred and ninetyeight million (Duruiheoma, 2018). It is comprised of three hundred and eighty-nine ethnic groups and six geopolitical zones (National Population Commission, 2014) viz: South-East, South-South, South-West, North-East, North-Central and North-West.

Since 2009, the North-East had been ravaged with terroristic act by a group called Jama'atuAhlisSunaLidda'awati WalJihad also known as "Boko Haram" and as a result of this terrorism, a verified two million people (Amnesty International, 2015) had been caused to flee to other parts of the country and at least another 150,000 people have taken refuge in neighboring countries like Chad, Niger and Cameroon (although the numbers are daily growing).

The biological, psychological, physical, economic as well as social effects of terrorism with such magnitude of violence as employed by Boko Haram cannot be overemphasized as they are in most circumstances very glaring. The social effects that accentuate such environments do not just terminate with the victims alone (first degree) but pervade the entire society (second degree) and in most cases, are trans-generational as is the case in Palestine (Speckhard, 2008).

Boko Haram began as a social movement with considerable popularity. Its members were predominantly young men who joined the sect voluntarily. As the group's influence grew, so did its financial resources, which were used to recruit new members. (Oriola, 2017)

Young unemployed men found themselves with money, access to weapons and the power to extort money from others in society. Amnesty International learnt from one of the members of the Civilian Joint Task Force how Boko Haram took advantage of the idleness of these young men especially in Konduga, Borno state and other parts of the North-Eastern states. To him, "They didn't have work to do, so Boko Haram gave them guns" (Amnesty International, 2015).

Due to the wide acceptance of the group among the economically and socially displaced and marginalized youths from the abinitio, Boko Haram gained ground in the North-East Nigeria and had used the opportunity to wreak havoc on individuals especially the perceived infidels. Owing to the high or seeming religiosity and the multi-religious practices of Nigerians, it is often common for religion to cause disputes among the various inhabitants especially among the fanatics. In Nigeria, religion had often been used to justify even the slightest of mundane and political actions and errors (Adesoji, 20117) i.e. religion had been a basis for almost all actions of people both in the political sphere and others. Every thought or view in the Nigerian context is filtered through religion. It is the opinion of Adesoji (2017) that the Sharia debate in the Constituent Assembly between 1977 and 1978 was the first incidence to majorly polarize Nigeria along religious lines. But the Islamic fundamentalism can be traced back to the 1980's which saw to the "Maitatsine" uprising as was led by Muhammadu Marwa (Adesoji, 2011). 


\section{HISTORICAL OVERVIEW OF BOKO HARAM}

Although there is the dispute among scholars on the emergence of Boko Haram, they most often concur on the radicalization of the group (Oriola, 2017). The detonation of a bomb in Maiduguri in July 2009, the police arrest of eight Boko Haram members and seizure of their arms and explosives, the violent engagement of the police by Boko Haram members and the resultant killing of Police officers, the burning of several churches and government buildings purportedly to secure the release of their then arrested leader, Mohammed Yusuf, the deployment of the Nigerian military's Joint Task Force (JTF) led by Colonel Ben Ahanotu to nip the deteriorating crisis in the bud and their subsequent success in arresting Mohammed Yusuf, Boko Haram's leader on 30 July, 2009 (who was immediately handed over to the police for prosecution) and his subsequent killing by the police officers are all chronologically the leading events that brought Boko Haram to the limelight (Oriola, 2017) (despite its existence before then).

Consequently, and subsequently, Boko Haram invaded a prison in Bauchi State on 8 September, 2010 and released its incarcerated members. The organization's terrorist activities intensified thereafter (Oriola, 2017). Oriola and Akinola, (2017) gave a chronology of the spread of the group and they submitted that after the radicalization of Boko Haram based on the above factors, it spread from one state (Borno in the Northeast) to 17 states in 2014. Until the first quarter of 2015, Boko Haram was believed to be in control of at least 14 local governments in three Nigerian states: Adamawa, Yobe, and Borno. Boko Haram kidnapped 276 high school girls in Chibok, Borno state in April 2014 (this act was seen as the major event that endeared the organization to the world like the USA and subsequently made the world to label it an international terrorist organization). Its campaign has been marked with mass killings since its radicalization, such as the murder of 59 high school boys in Buni Yadi, Yobe state in February 2014, the killing of nearly 400 people during a raid on Gamborou in Ngala Local Government Area of Borno state on $5^{\text {th }}$ May 2014, there was also the overrunning of the 350 soldiers stationed in Gwoza which resulted in the killing of at least 600 civilians on $6^{\text {th }}$ August 2014 (Amnesty International, 2015). These killings and kidnappings highlight the brazen attacks on young people by Boko Haram. Amnesty International (2015) believes that Boko Haram has also exterminated over 20,000 people and injured thousands of others. In addition, over two million people (and growing) are either internally displaced within Nigeria or have become refugees in neighboring countries.

Oriola and Akinola, (2017) went ahead to analyze the destructive nature and the lethality of Boko Haram by juxtaposing it with the Islamic State of Iraq and Syria (ISIS). They opined that while on average of 15 persons were being killed in each of Boko Haram's attacks; each ISIS's attack had killed seven persons on the average. Between 2009 and 2014, Boko Haram's attacks in Nigeria were primarily targeted at (a) private citizens and properties, and (b) the police (Oriola and Akinola, 2017), but today, the case is different as more and more of public facilities are being targeted as in the most recent incessant bombings of the University of Maiduguri (a Federal University) between 26 June and 13 July 2017 (Vanguard, 2017).

\section{YOUTHS AND TERRORISM: GENERAL CONSEQUENCES}

Although the effects of terrorism range from psychological, economical to social deprivations etc. it had been argued by Sadock and Sadock (2005) that the social effects are more pronounced and could affect generational structures and 
also deter the effective functioning of the entire society trans-generationally. These social effects and their negative impacts on young people within the ages of 13-24 are hereunder espoused.

For easy comprehension, the victims of the terroristic act of Boko Haram are classified into two on the basis of first-degree victims and second-degree victims. The first degree victims are the individuals who are kidnapped, killed, maimed, raped, injured, molested and terrorized by the perpetrators of the terror and the soldiers who are at the forefront of the war against the terrorists while the second degree victims are the relatives of the first degree victims and of course, the wider society (even the international community) who watch, read and hear about these terrorist acts. The above suggests that every individual in Nigeria is directly or indirectly a victim of Boko Haram. On the psychological scale, terrorism causes psychological trauma which results in helplessness in the face of intolerable danger and anxiety.

Most of these young ones suffer from post-traumatic stress disorder (PTSD) which affects the cognition, emotions, interpersonal relations, and personality development. The most common effect is an enduring sense of pessimism with depression and suicidal ideations. The symptoms of depression and anger are much higher in young people who experience these terroristic acts on a first-degree level.

A study carried out on Palestinian youths by Ahmed (2007) and published in the Journal of Islamic Medical Association showed that on average; almost every Palestinian aged 7-24 has witnessed about ten traumatic incidents in a lifetime. The traumatized individuals show a range of symptoms including insomnia, nightmares, hyper vigilance, and severe agitation. People with adverse stress reactions and behavioral symptoms longer than one month may be at increased risk of developing PTSD or violent and delinquent behavior later in life. Stress of trauma is experienced when an individual (a child or an adult) is confronted with a situation that is personally threatening to self or others.

It is now established that stress caused by emotional trauma during early development, permanently affects

the brain circuits critically. These mental scars then lead to altered behavioral and physiological responsiveness to the environment that ultimately increases the likelihood of adult psychopathology (Ahmed, 2007). The children and adolescents with traumatic grief are four times more likely to have suicidal thoughts. According to a study by Davidson, 19\% of PTSD patients may ultimately commit suicide which according to Durkheim (1970, first published in 1897) is a social effect that is detrimental to the society at large.

\section{SOCIAL EFFECTS}

Socially, the effects of terrorism on young people as can be found in the North-East Nigeria could be explained under these sub-headings; First, Boko Haram has grossly affected religion in the North-East, Christianity, Islam and other traditional religions alike. The group had issued public demands (at the early stage of their radicalization) that Christians should leave northern Nigeria but subsequently attacked Muslims and traditional worshippers who do not share in their religious views. It has burned down churches and mosques, killed worshippers of both faiths. It has abducted women and girls and threatened them with violence in order to force their conversion to their own version of the Islamic religion or marriage to its members. Men who refuse to convert have been killed and it has also attacked traditional Muslim leaders who have condemned its tactics, and targeted their families (Human Rights Watch, 2014). 
The most rampant and lethal terror of ages had been attributed to religion (Zaidi, 2009). By this, there is the breach of the fundamental right to worship. Young people are now afraid to choose a religion compatible with their beliefs, conscience and consciousness but are subjected to the tenets of a religion they know little or nothing about. Through this, the relationship between humans and their supreme being (what they call God) is flawed consequently leading to the inefficacy of religion as a means of social control (Durkheim, 1912). Sand (1887) posited that a man's religion is a man's code of moral ethics. If he has no moral ethics, he may worship forever yet he will still be minus religion in its true sense. Sand (1887) added that the man who participates in public worship, for the mere sake of seeming religious, is viler and lower than the meanest of animate creations. His whole life is one of harmfulness, deception, and treachery.

Durkheim (1912) argued that religion is, in a sense, the celebration and even (self-) worship of human society. Based on this approach, Durkheim submitted that religion is functional to the society in three major ways which are;(a) it provides social cohesion to help maintain social solidarity through shared beliefs, (b) a means of social control to enforce religious-based morals and norms to help maintain conformity and control in society, and (c) it offers meanings and purposes to answer any existential questions. Religion, for Durkheim as captured by Boundless (2016), is not imaginary, religion in and around itself is very real; it is an expression of society itself, and indeed, there is no society that does not have religion, even in its most rudimentary form. We perceive as individuals a force greater than ourselves and give that perception a supernatural face. We oftentimes express ourselves religiously in groups, which for Durkheim, makes the symbolic power greater. Religion is an expression of our collective consciousness, which is the fusion of all of our individual consciousness that then creates a reality of its own.

To this end, the importance of religion (Christianity, Islam, Traditional religions etc.) in the society (NorthEast inclusive) cannot be overemphasized. From time immemorial, religion had been one of the strongest tools that mold and shape the characters of individuals into conformity with the normative provisions of the society but the breakdown of such leads to a geometric increase in crime and social demoralization (as it is a succor to the individual soul).

Second, the terroristic act perpetrated by Boko Haram in the North-East is very consequential on young people in respect to the destruction of social networks and supports. For instance, there is the unfathomable psychological trauma that is ushered in by a scenario where a young person is constantly raped, dictated to and commanded by his or her former classmate at school. Below is an excerpt of an interview granted Amnesty International by a 19-year-old Aisha Yusuf who was abducted in September 2014.

"I was raped several times when I was in the camp, sometimes five of them, sometimes three and sometimes six. It went on for all the time I was there. It always happened in the night... Some were even my classmates or from my village. Those who knew me were even more brutal to me." (Amnesty International, 2015:64). 
Victims of such circumstances see no benefit in social networks and are bound to reject them in future times. They may often not see anything good in peer relationship having witnessed the agonies such as that thus; the destruction of social networks.

Another dimension to this (as to the destruction of social networks) is the horrible decisions mothers are forced to make in other to escape from the den of Boko Haram. For instance, Oriola (2017) narrated the ordeal of the kidnapped women and the dehumanizing decisions they made when he submitted that;

"Some of the mothers among Boko Haram's kidnapped victims appeared to have been forced to make inhuman decisions that could potentially cause them to question their competence as women and mothers. This is a salient matter in patriarchal societies. One woman, Margaret, who had five children, was kidnapped while she had gone out with two of her children. She fled after several months with one child, leaving the other behind when she had the opportunity to escape from her captors. Margaret realized that it was not possible to escape with two young children, so she left, placing a child in the care of fellow abductees. Margaret was lucky to find the child she was forced to abandon alive in an Internally Displaced Persons (IDP) camp. The impact of such life and death decisions on a mother is profound" (Oriola, 2017:14).

The question posed by a scenario like this is how would the child who was abandoned but later found in an Internally Displaced Persons camp feel about her mother? A child like that grows up or lives the rest of her life with the subconsciousness that when she is in danger, she is standing alone as his family would disappear at the flip of the finger. A child like that would seldom do anything to further the course and interests of family. To a child such as that, the family as an institution is of little or no importance thus, the destruction of social networks.

The next dimension to this is a situation where a child feels she is unimportant to her family because of her gender (which is not of her own making), for instance when a father ungrudgingly 'sells' his daughter to a terrorist group irrespective of the reasons (whether for the pecuniary gain or for the sheer love and sympathy for the course so far). "There is evidence suggesting that some fathers have been handing over their female children and/or wives to Boko Haram." (Oriola, 2017:8)

The importance of the family as an institution to the likes of people in the category above is grossly diminished and in circumstances where they have to make decisions that invariably affect the family (which is the microcosm of the society), they are readily going to be irrational and in most cases, inconsiderate.

Third, there is the issue of functional impairment, in a study carried out by Oriola (2017) on the use of women as a gendered tool for the perpetration of the course of Boko Haram, he discovered evidences suggesting that some fathers had been deliberately handing over their female children and/or wives to Boko Haram (which may involve exchange for cash or outright donation). For instance, 13-year-old Zahharau Babangida, who abandoned a bomb she was meant to detonate in 2014, claimed that her father donated her and her mother to Boko Haram. To him, the gendered gifting posits the relationship of women to men and the hierarchical power structure in such society. These dimensions generally point to the infinitesimal value of women in such highly patriarchal society. 
The dehumanizing effect of this kind of act cannot be overemphasized. The nightmarish thought of the fact that a father could wake up one morning and decides to gift his daughter or wife to a terrorist group either to further the cause of their actions or in exchange of a minute kickback is negatively affective. Its effects are not limited to only the people that are gifted out but also to a group of young people who are of the same age range in the wider society. These sets of people are functionally impaired in the society as such an act tries to prove to them how little or not of any value they are in the society. In every role they take up in their life both during and after the terrorism era, they will still remunerate on the infinitesimal value of their gender and may not function at their best capacity thus, the underdevelopment of the society.

On the other hand, parents (especially mothers) who have for some reasons, abandoned their children in Boko Haram camps and scampered for safety have lost their sense of motherhood and are too morally dehydrated to function as parents in the society. The thought of abandoning their children in a war zone, the feeling of helplessness in discharging their roles as parents could induce the sense of incompetence as parents and thus, the impairment of family roles.

Fourth, there is conduct disorder (i.e. deviance) which is made obvious in the intractable nature of some wars in the Middle East. There are evidences showing that wars and terrorism of a particular age and dispensation do not always end with the generation of those that begin it (Speckhard, 2007). If it were so, the world would not have been experiencing terrorist attacks today. It has been argued overtime that the more a child is exposed to violence and war, the more chances he/she would become violent (Alobo and Obaji, 2016). The continuous exposure of young people in the North-East to the deadly acts of Boko Haram overtime creates a lacuna in the social order which makes it difficult (if not impossible) for the individuals to process and differentiate between orderliness and disorderliness, good and bad. In Bama for instance, 15-year-old Mustapha Saleh witnessed a public stoning of five men and five women for adultery in February 2015: he decried in his speech how the authorities sentenced them to death, called the residents and told them to stone them and how he was forced to participate in the stoning. "They dig a hole, bury all the body and stoned the head. When the person died, they left them" (Amnesty International, 2015).

Acts like these create a generation of stone-hearted individuals, a generation with lack of conscience and social morality. The assumed incentives like killing at will, looting of people's properties with the use of coercion, sexual satisfaction (whenever, wherever and however it is wanted) through rape, exerting obedience through the use of or the threat of force etc. all reinforce deviance and disorder in the society and the young ones overtime get conformed to the existing lifestyle.

Fifth, there is the destruction of social capital like shared values, morale and cohesion. As was coined from an interview granted HART foundation in 2015 by a13-year-old boy named Isa,

"My whole family left Gwoza because of the increasing fighting and attacks. We heard that the militants were moving around the town; that Boko Haram was said to be gone but it was a trick. Any people who returned to their villages... Boko Haram cut their throats. I am not sure how many people were killed and how many dead bodies. There was one man who was told to lie on the 
ground, and then they pushed and held him down while they cut through his neck from the back to cut his head off. My whole family saw it" (HART, 2015:7).

Another interview as granted by a female interviewee recounted that,

"In a village near my hometown Boko Haram gathered the youths together and started slaughtering them all...They were killed with guns or knives, sometimes they take away their heads" (HART, 2015:7).

Owing to the above, researchers like Sadock and Sadock (2005) have proven that the consistent terrorist attacks on US soil over the years like the World Trade Center bombing of 1993, the Oklahoma City bombing of 1995, the attack on US embassy in Nairobi, Kenya in 1998 and the attacks of both the Pentagon and the World Trade Center in 2001, have made some examined individuals to resort to self-defense. These and many other internal terrorist attacks could explain in a way the proliferation of civilian firearms as could be found in American today.

The destruction of social capital is one of the devastating effects of terrorism on a growing generation as they consequently jettison morale and shared values and resort to improvised ways of acting for instance, the uncertainty of one's life, the threat of an imminent attack, the fear that a bomb could detonate at any time could psychologically reshape the behavior of the young because they invariably remunerate on these things overtime in the course of their life. Those who survive the attacks are made to lick the wounds thereof by living with the nightmarish outcomes.

Sixth, there is the destruction and the alteration of social institutions. Wars and insurgences are usually meant to either alter the status quo or to induce a new social order. Either ways, wars have been generally postulated as a major tool that alters the social institutions. This alteration invariably affects the young ones especially in the case of terrorism in North-East Nigeria. For instance, Amnesty International (2015) submitted that in March 2014, the Borno state government decided to close all secondary schools in the state in order to protect students and teachers from further attacks. The state government announced that all schools would be reopened in November 2014. This closure altered the academic calendar of the state which invariably had placed a pause on the formal acquisition of knowledge. "Although there were fewer restrictions on men, Boko Haram had killed or imprisoned many men of fighting age," in effect, the labor force (Amnesty International, 2015). This submission by Amnesty International is informing us that there is already interference in the composition of the work force of the North-Eastern societies.

The destruction of social capital by the war perpetrated by Boko Haram is very particular to the North-East Nigeria due to the adverse effects of the gendered nature of their new tactics of suicide bombing. The aptness of this is that most of the women used by Boko Haram to perpetrate suicide bombings are mostly young.

Oriola (2017) submitted a trace of the effects of Boko Haram's deployment of these young women in suicide bombing. At the individual level, he opined that "Boko Haram's strategy strips kidnapped women and girls of their sense of self or identity. People's sense of self is closely tied to their religious identity. Boko Haram engages in forced conversion of kidnapped women and girls to its version of Islam. For instance, Mohammed Shekau released a video that showed the Chibok girls reciting the Quran. He argued that the "girls from Chibok confessing Islam is the true 
religion!" This effort includes having the girls "dressed in full-length hijab, with only faces and hands showing," which is different from their earlier dressing patterns as predominantly Christian girls" (Oriola, 2017).

At the family/communal level, Oriola (2017) further submitted that as Zainab Bangura, UN special representative of the secretary-general, pointed out: "Boko Haram is not only destroying existing family and community structures but is bent on controlling their future composition. Given the prevalence of gender norms within a patriarchal society, the bodies of women and girls become the soil on which Boko Haram plants its seeds of destruction (Oriola, 2017). This harms physically and psychologically not just the primary victims; it damages the collective identity of their families, religious group, and ethnic community. It also demoralizes and emasculates the men in such affected communities (Oriola, 2017).

All the above consequences are geared towards the conscious and unconscious alteration or a complete annihilation of the family system as a social institution. It could inferentially be submitted that by the end of the terrorism in the North-East, women of marriage age range would have probably been either totally annihilated or in a very minute number which invariably raises a question of procreation and the sustenance of the ethnic group.

\section{THEORETICAL REPRESENTATION}

Theoretically, the social quagmire which has led to the destruction of and the de-capitalization of social gains in the North-East vis-à-vis young people can be theoretically viewed from the functionalist lenses. The aptness of this theory (structural functionalism) in the explanation of the terror rained by Boko Haram on the young and future generation of the North-East (and consequentially, the wider Nigeria) is owed to the functional prerequisites of Talcott Parsons.

Functionalism is majorly rooted in the works of Talcott Parsons who exposed sociologists to the understanding of how the different social institutions in the society function in a united manner for the common good of the larger society. Functionalism as captured by Haralambos and Holborn (2008) views the society as a system i.e. as a set of interconnected parts which form a whole. Parsons argued that an understanding of any part of the society is made possible through the understanding of the whole vice-versa.

To this end, the emergence of Boko Haram which is owed to the failure of the Nigerian state (Oriola and Akinola, 2017), the unflinching, strict and twisted adherence to religion (Amnesty International, 2015) and the western educational resistance which are the institutional courses of the terrorism are to be lucidly understood through functionalism. The emergence of Boko Haram had been remotely traced to the gross failure of the Nigerian government to carry out its basic functions as to the provision of basic amenities and the amelioration of social, economic and political lives of its citizens. There is the feeling of marginalization of the people by the government at the local, state and the federal levels; they have failed to provide good and motor-able roads, potable water, and a considerable amount of electricity for the poor and yearning masses. And consequent upon these factors, the masses had resorted to violence.

Parsons (1951) argued that the sustenance of any social system is hinged upon the effective workability of every societal institution and that anomalies that are found in one (if not immediately checked and fixed) automatically results in the malfunctioning of the whole society. He identified some functional prerequisites i.e. those necessities that ultimately sustain the society (Haralambos and Holborn, 2008) and they are; (a) Adaptation: which determines 
the level/degree of control of a social system on its environment. Food and shelter must be provided to meet the needs of its continuous existence and this is the basic function of the economic system. (b) Goal attainment: to Parsons, the society needs to set collective goals for its members and also allocate resources for their attainment. This is the peculiar function of the political institution. (c) Integration: this is the conscious adjustment and mutual coordination of the parts of the societies and to Parsons (1951), the legal institution is bestowed with this responsibility and, (d) Latency also referred to as pattern maintenance: which is the maintenance of the basic patterns of the society. This function is collectively discharged by religion, family and education.

The importance of adaptation, goal attainment, integration and latency postulation of Parsons as presented above had been either grossly misapplied or jettisoned in the North-Eastern part of Nigeria which informs the emergence of conflict and ought to be immediately retraced. The religious, educational, family and the political institutions have not been discharging their functions in a way that could maintain social equilibrium (Haralambos and Holborn, 2008).

All the above-mentioned institutions had been dysfunctional (Merton, 1968) to some degree which explains why religion which manifestly ought to be a source of social control and integration is in this case, has become a source of terror. Education which ought to be one of the major sources of socialization is now an alienating force. The government (political institution) which ought to be a major vanguard of peace is now a major push for the emergence of terrorism.

The second dimension of the application of this theoretical postulation of Parsons to the topic under study is the linkage of the effects of terrorism on young people. There is the chain-like reaction of the effects of terrorism on young people as this set of people represents a significant part of the society and are soon the generation of parents that are tasked with socializing the young ones also. The faults of today automatically amount to the malaise of tomorrow.

The division of the victims of terrorism into first degree and second degree suggests also the aptness of this theory. It suffices to say that technically no one in Nigeria is exempted from being terrorized by Boko Haram because of the interwoven nature of the society.

\section{CONCLUSION}

Terrorism by Boko Haram had affected a significant number of people in the Northern part of Nigeria since 2009, a significant number of them had died in many draconian ways and quite a reasonable number of them had been displaced and unfortunately the statistics are still growing due to the almost daily attacks perpetrated by Boko Haram. To this end, the social effects vis-à-vis young people, ought to be scholarly documented which are; the effect on religion, destruction of social networks and support, functional impairment, conduct disorder i.e. deviance, destruction of social capitals and destruction of social institutions. The use of structural functionalism and the incorporation of the ideas of both Talcott Parsons and Robert K. Merton had given a more structural understanding of the aforementioned effects. 


\section{RECOMMENDATIONS}

Since there is the general acceptance of the factors that led to the emergence of Boko Haram in the scholarly world, among which is the failure of the Nigerian state, the political institution ought to increase its odds and create more enabling environment for the survival of the people in the society. The government should do more in delivering the dividends of democracy to the grassroots.

There should be the reinforcement of the fundamental tenets of religion of any kind and the de-radicalization of same. Elements of religious fanaticism should not be tolerated by any religion and any trace of it should be tactfully tackled at its early stage to avoid escalation.

There should be a re-visitation and exploration of the informal type of education which was in existence even before the introduction of the formal western-oriented learning. The perpetrators of the terrorist acts in the North-East have rejected western education; they should then be made to explore the informal education as that was efficacious in the transmission of values until the advent of the formal education as we have it today.

\section{REFERENCES}

Adesoji, A. O. (2011). Between Maitatsine and Boko Haram: Islamic fundamentalism and the response of the Nigerian state. Africa Today, 57 (4): 98-119. DOI: 10.1353/2011.0016

Ahmed, M. D. B. (2007). Effects of terrorism on children's psychosocial and biological understanding. Journal of the Islamic Medical Association, 39 (2): doi:10.5915/39-2-6491

Akinola, O. (2015). Boko Haram insurgency in Nigeria: between Islamic fundamentalism, politics, and poverty. African Security, 8 (1): 1-29. DOI:10.1080/19392206.2015.998539.

Amnesty International. (2015). Stars on their shoulders, blood on their hands. War crimes committed by the Nigerian military. Retrieved on $8^{\text {th }}$ June, 2019 from

https://www.amnesty.org/download/Documents/AFR4416572015ENGLISH.PDF

Amnesty International. (2015). Our job is to shoot, slaughter and kill: Boko Haram's reign of terror in North-East Nigeria. Retrieved on $9^{\text {th }}$ June, 2019 from: https://www.amnesty.org/download/Documents/AFR4413602015ENGLISH.PDF

Boundless. (2016). Functions of religion. Boundless Sociology. Retrieved $9^{\text {th } J u l y ~} 2019$ from: https://www.boundless.com/sociology/textbooks/boundless-sociology-textbook/religion-14/thefunctionalist-perspective-on-religion-106/functions-of-religion-593-8141/

Davidson, J. R., Hughes, D., Blazer, D. G., and George, L. K. (1991). Post-traumatic stress disorder in the community; an epidemiological study. Psychological Medicine, 21 (3):713-721.

Durkheim, E. (1912). The elementary forms of the religious life. London: George Allen \& Unwin Ltd.

Durkheim, E. (1970). Suicide: A study in sociology. London: Routledge and Kegan Paul.

Duruiheoma, E. (2018). Nigeria's population hits 198m people. Retrieved on 12 May, 2018 from http://population.gov.ng/nigerias-population-hit-198m-people-npopc-chairman/ 
Haralambos, M., Holborn, M., and Heald, R. (2008). Sociology, themes and perspective. London: Harpercollins Publishers Limited.

HART. (2015). Some will die, but we will not all die. Those that can carry on must keep hope alive. HART Nigerian Visit Report on the Northeast. Retrieved on $4^{\text {th }}$ July, 2019 from www.stefanosfoundation.org

Human Rights Watch. (2014). Those terrible weeks in their camp: Boko Haram violence against women and girls in Northeast Nigeria. Retrieved on $6^{\text {th }}$ July, 2019 from: https://www.hrw.org/report/2014/10/27/those-terribleweeks-their-camp/boko-haram-violence-against-women-and-girls

National Population Commission, (2006). National population census. Abuja. Federal Government of Nigeria.

National Population Commission, (2014). Nigeria demographic and health survey 2013. Abuja. Federal Government of Nigeria.

Oriola, T. B. (2017). Unwilling cocoons: Boko Haram's war against women. Studies in Conflict \& Terrorism, 40 (2): 99-121.DOI: 10.1080/1057610X.2016.1177998

Pynoons, R. S., Schreiber, M. D., Steinberg, A. M. and Pfefferbaum, B. J. (2005). Impact of terrorism on children. In Sadock, B. J. and Sadock, V. A. (eds), Kaplan and Sadock's comprehensive textbook of Psychology (pp. 3551-3564). Philadelphia: Lippincott Williams and Wilkins.

Sand, G. (1887). Religion. The North American Review, 144(362): 106-107. Retrieved on $9^{\text {th }}$ July, 2019 from http://www.jstor.org/stable/25101166

Speckhard, A. (2007). The emergence of female suicide terrorists. Studies in Conflict and Terrorism,31:1023-1051. DOI: $10.1080 / 10576100802408121$

Temitope, B. O. and Olabanji, A. (2017). Ideational dimensions of the Boko Haram phenomenon. Studies in Conflict and Terrorism, 0 (0): 1-24. DOI: 10.1080/1057610X.2017.1338053

United Nations Organization. (1981). Definition of youth. Secretary-General's Report to the General Assembly, $A / 36 / 215$. Retrieved on $10^{\text {th }}$ July, 2017 from http://www.un.org/esa/socdev/documents/youth/factsheets/youth-definition.pdf

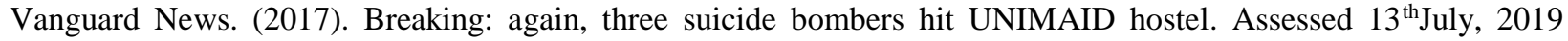
from http://www.vanguardngr.com/2017/07/breaking-again-three-suicide-bombers-hit-unimaid-hostel

Zaidi, M. (2009). A taxonomy of Jihad. Arab Studies Quarterly, 31 (3): 21-34. 